Çukurova Üniversitesi Mühendislik Mimarlık Fakültesi Dergisi, 33(3), ss. 11-22, Eylül 2018

Çukurova University Journal of the Faculty of Engineering and Architecture, 33(3), pp. 11-22, September 2018

\title{
Lojistik Regresyon Analizi ile Bir Yeraltı Metal Madeninde Gürültüye Bağlı İşitme Kayıplarının İncelenmesi
}

\author{
Seyhan ÖNDER ${ }^{* 1}$ \\ Eskişehir Osmangazi Üniversitesi, Mühendislik Mimarlık Fakültesi, Maden Mühendisliği \\ Bölümü, Eskişehir
}

Geliş tarihi: 25.05 .2018

Kabul tarihi: 15.10 .2018

$\ddot{\mathbf{O z}}$

Madencilik sektörü, içerdiği riskler açısından değerlendirildiğinde diğer sektörlere göre, çalışanlarının meslek hastalıkları yaşama olasılığı oldukça yüksek olan bir iş koludur. Meslek hastalıklarının tümüyle önlenebilmesi için, oluşum koşullarının belirlenmesi ve önleyici tedbirlerin alınması gereklidir. Bu çalışmada, yeraltı üretim yöntemi ile işletilen bir metal madeni işletmesinde, gürültü düzeyleri ile gürültüye bağlı işitme kayıplarının arasındaki ilişki lojistik regresyon analizi ile incelenmiştir. Gürülttüye bağlı işitme kaybı üzerinde etkisi olan parametreler; çalışanların maruz kaldıkları gürültü düzeyleri, ortamdaki gürültü düzeyleri, meslek grupları, yaş ve deneyim süreleri olarak belirlenmiş̧ir. Çalışma sonucunda, işitme kaybında en etkili olan parametreler belirlenmiştir.

Anahtar Kelimeler: Gürültüye bağlı işitme kaybı, Madencilik, Lojistik regresyon analizi

\section{Investigation of Noise Induced Hearing Loss with Logistic Regression Analyses in an Underground Metal Mine}

\begin{abstract}
When considered in terms of the risks involved, the mining is a sector that is highly likely to have occupational diseases when compared to other sectors. In order to prevent occupational diseases completely, it is necessary to determine occurrence conditions of occupational diseases and take preventive measures. In this study, the relationship between noise levels and noise induced hearing losses in a metal mine operated with underground production method was investigated by logistic regression analysis. Parameters affecting noise induced hearing loss were determined as the noise levels that the employees are exposed to, the noise levels in the environment, occupational groups, age and experience. As a result of the study, the most effective parameters for noise induced hearing loss were determined.
\end{abstract}

Keywords: Noise induced hearing loss, Mining, Logistic regression analysis

*Sorumlu yazar (Corresponding author): Seyhan ÖNDER, sonder@ogu.edu.tr 


\section{GíRiș}

Madencilik sektöründe meslek hastalığı olușturma ihtimali yüksek olan önemli tehlikelerden birisi gürültüdür [1]. Meslek hastalıkları, işyeri ortamında bulunan faktörlerin etkisi ile meydana gelen hastalıkların ortak adıdır. Meslek hastalıkları etkenle çalışanın ilk temasından 1 hafta ile 30 yıl sonra ortaya çıkabilmekte olup, tümüyle önlenebilir hastalıklardır. Yalnızca tek bir etmenin değil, birçok etmenin bir arada etkilediği olgulardır. Mevzuatın öngördüğü periyodik ortam ölçümleri ve sağlık muayeneleri ile çalışanların herhangi bir şikâyeti ortaya çıkmadan meslek hastalıkları tespit edilebilmekte ve gerekli önlemler alınmasına imkân bulunabilmektedir.

Dünya Sağlık Örgütü ve Uluslararası Çalışma Örgütü gibi uluslararası kaynaklarda meslek hastalıkları; zararlı bir etkenle bundan etkilenen insan vücudu arasında, çalışılan işe özgü bir nedensonuç, etki-tepki ilişkisinin ortaya konabildiği hastalıklar grubu olarak tanımlanmaktadır. 5510 Sayılı Sosyal Sigortalar ve Genel Sağlık Sigortası Kanunu'nun 14'üncü maddesinde "Meslek hastalığı, sigortalının çalıştı̆̆ veya yaptığ niteliğinden dolayı tekrarlanan bir sebeple veya işin yürütüm şartları yüzünden uğradığı geçici veya sürekli hastalık, bedensel veya ruhsal engellilik halleridir." şeklinde tanımlanmaktadır.

Türkiye'de meslek hastalıkları Sosyal Sigorta Sağlık İşlemleri Tüzügü̈nde Çizelge 1'de verildiği gibi sınıflandırılmıştır [2].

Çizelge 1. Meslek hastalıkları sınıflandırması

\begin{tabular}{|l|l|}
\hline A Grubu & $\begin{array}{l}\text { Kimyasal maddelerle olan meslek } \\
\text { hastalıkları }\end{array}$ \\
\hline B Grubu & Mesleki deri hastalıkları \\
\hline C Grubu & $\begin{array}{l}\text { Pnömokonyozlar ve diğer mesleki } \\
\text { solunum sistemi hastalıkları }\end{array}$ \\
\hline D Grubu & Mesleki bulaşıcı hastalıkları \\
\hline E Grubu & $\begin{array}{l}\text { Fiziksel etkenlerle olan meslek } \\
\text { hastalıkları }\end{array}$ \\
\hline
\end{tabular}

Çizelge 1'de verilen etkenler değerlendirildiğinde, gürültüye bağlı işitme kayıpları "Fiziksel etkenlerle olan meslek hastalıkları" olup "E Grubu" olarak tanımlanmaktadır. Gürültü, "hoşa gitmeyen, istenmeyen, rahatsız edici ses" olup, ciddi fizyolojik, psikolojik ve sosyal etkilere neden olmaktadır [3]. Gürültü, insan sağlığı üzerine işitme kaybı gibi olumsuz etkiler yaratmakla birlikte [4,5], çalışanların verimini de olumsuz yönde etkileyebilmektedir. Gürültünün meydana getirdiği fizyolojik etkilerde, işitme kayıpları bilinen olumsuz etkilerin başında gelmektedir. İşitme zararları genellikle gürültünün şiddetine, gürültünün sürekli/kesikli olmasına, yaşa, gürültülü ortamda geçirilen toplam zamana, gürültüye olan duyarlılığa ve vücuttaki fizyolojik durumuna bağlıdır. Uzun süreli şiddetli gürültüye veya $87 \mathrm{~dB}(\mathrm{~A})$ 'nın üzerindeki seslere maruz kalan kişilerde geçici veya sürekli işitme kaybı oluşur. Psikolojik ve sosyal etkilerde; hoşgörünün azalması, davranış bozuklukları, öfkelenme, rahatsızlık duygusu, sıkılma sayılabilir. Performans üzerine etkilerinde; karşılıklı konuşmanın etkilenmesi, dinleme ve anlama güçlüğü, yüksek sesli konuşma, insan iletişiminin bozulması, konsantrasyonun ve iş performansının etkilenmesi sayılabilir. Çalışma hayatında yüksek düzeyli, ani veya kesikli gürültüler iş verimini olumsuz etkilediği gibi işin zamanında ve doğru olarak yapılmamasına ve iş kazalarına neden olabilir.

Gürültü değerlendirme ölçüsü, ses basıncı seviyesine dayanan desibel $(\mathrm{dB})$ 'dir. Gürültü seviyesinin ölçüsü, kullanılan ağırlık eğrisine göre $\mathrm{dB}(\mathrm{A})$ ya da $\mathrm{dB}(\mathrm{C})$ 'dir. İnsan kulağının frekansa bağlı olarak sese olan duyarlılığını en iyi A ağırlık eğrisi temsil eder. Bu nedenle genelde $\mathrm{dB}(\mathrm{A})$ olarak ölçülmektedir. Darbe gürültüsünün ölçüm ve değerlendirilmesinde ise $\mathrm{C}$ ağırlık eğrisi kullanılmakta ve $\mathrm{dB}(\mathrm{C})$ olarak ölçülmektedir [6].

28.07.2013 tarihli ve 28721 sayılı Resmi Gazete'de yayımlanarak yürürlüğe giren Çalışanların Gürültü İle İlgili Risklerden Korunmalarına Dair Yönetmelik'te en düşük maruziyet eylem değerleri: $\left(\mathrm{L}_{\mathrm{EX}}, 8\right.$ saat $)=80 \mathrm{~dB}(\mathrm{~A})$ veya $\left(\mathrm{P}_{\text {tepe }}\right)=112 \mathrm{~Pa}$ [135 $\mathrm{dB}(\mathrm{C})$ re. $20 \mu \mathrm{Pa}$ ] $(20 \mu \mathrm{Pa}$ referans alındığında $135 \mathrm{~dB}(\mathrm{C})$ olarak hesaplanan değer), en yüksek maruziyet eylem değerleri: $\left(\mathrm{L}_{\mathrm{EX}}, 8\right.$ saat $)=85 \mathrm{~dB}(\mathrm{~A})$ veya $\left(\mathrm{P}_{\text {tepe }}\right)=140 \mathrm{~Pa}[137 \mathrm{~dB}(\mathrm{C})$ re. $20 \mu \mathrm{Pa}]$, maruziyet sınır değerleri: $\left(\mathrm{L}_{\mathrm{EX}}, 8\right.$ saat $)=87 \mathrm{~dB}(\mathrm{~A})$ 
veya $\left(\mathrm{P}_{\text {tepe }}\right)=200 \mathrm{~Pa}[140 \mathrm{~dB}(\mathrm{C})$ re. $20 \mu \mathrm{Pa}]$ olarak verilmiştir [7].

Meslek hastalığı tanısı, o tanıyı alan çalışanın yakın çalışma arkadaşları için de erken tanı olanağı verir. Meslek hastalığı tanısı, beraberinde "tazminat", "yüksek iş göremezlik ödentisi”, "çalışma ortamının geliştirilmesi için yatırım” ve "cezai sorumluluk" getirdiği için, bir yanılgı ile saklanmaya çalışılabilmektedir [8]. Bu çalışmada, yeraltı üretim yöntemi ile işletilen bir metal madeninde, çalışanların gürültüye bağlı işitme kayıplarını incelemek amacıyla, çalışanların maruz kaldıkları gürültü düzeyleri, ortamdaki gürültü düzeyleri, meslek grupları, yaș ve deneyim süreleri göz önüne alınarak lojistik regresyon analizi kullanılmış ve işitme kayıplarının tahmini için bir model oluşturulmuştur.

\section{TÜRKIYE'DE VE MADENCILIIKTE MESLEK HASTALIKLARI}

Türkiye genelinde ve madencilik faaliyetlerinde 2011-2016 yılları arasında meslek hastalıklarına yakalanan sigortalı sayıları Şekil 1'de verilmiştir.

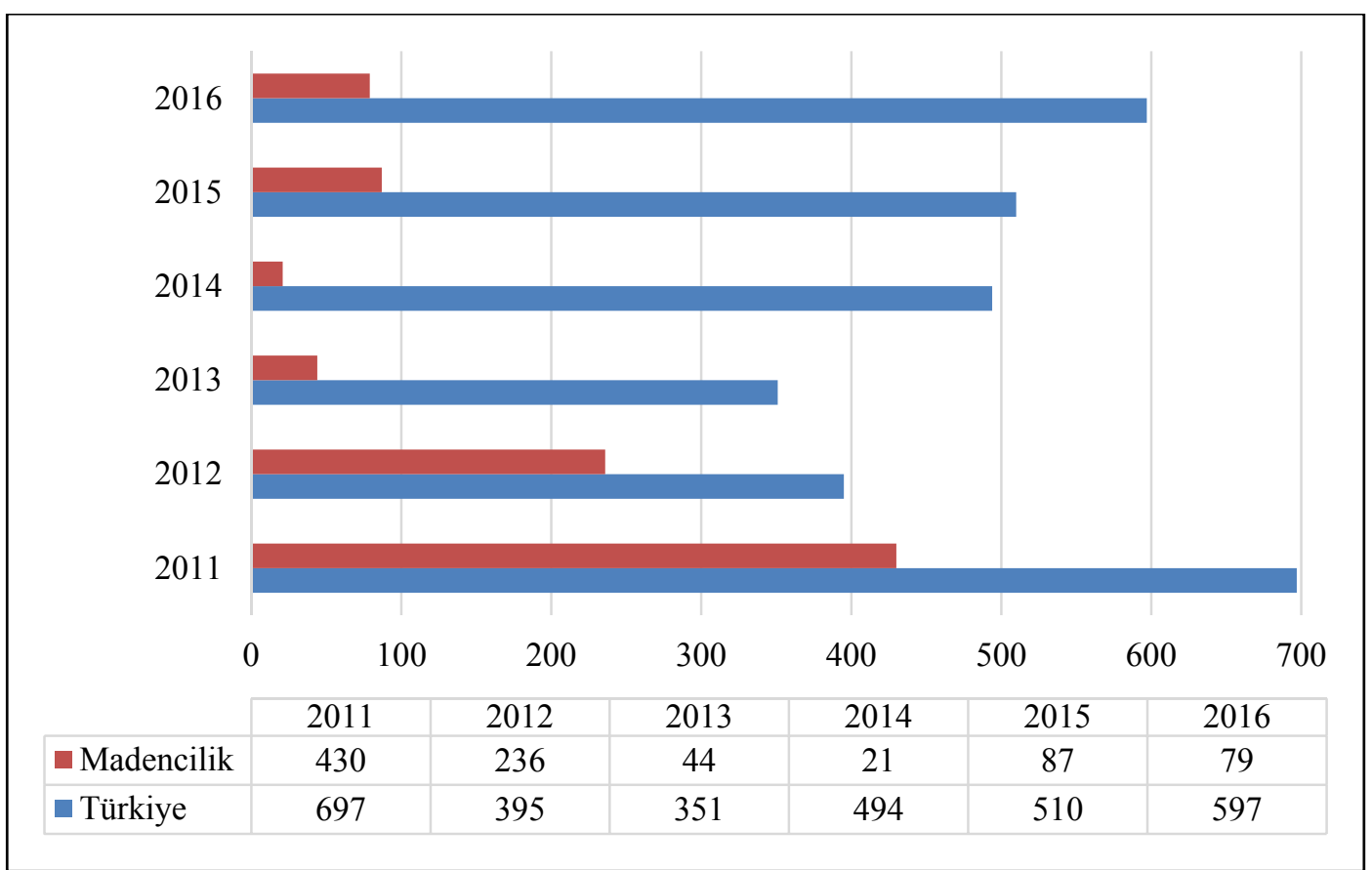

Şekil 1. Türkiye genelinde ve madencilik faaliyetlerinde meslek hastalıklarına yakalanan sigortalı sayıları [9]

Şekil 1 incelendiğinde, Türkiye genelinde meslek hastalıklarına yakalanan sigortalı sayılarının 351 çalışan ile en az 2013 yılında, 697 çalışan ile en fazla 2011 yılında olduğu görülmektedir. 2011-2013 y1lları arası azalma ancak bu yıllardan sonra yine bir artış dikkati çekmekte ve neredeyse eski yüksek seviyelere tekrar çıktığı görülmektedir. Madencilik faaliyetlerinde ise, 430 çalışan ile en fazla 2011 yllında ve 21 çalışan ile en az 2014 yılında olduğu görülmektedir. Ancak madencilik sektöründe meslek hastalıklarda ciddi bir düşüş olduğu dikkati çekmektedir.

Çalışmaya konu olan gürültüye bağlı işitme kayıpları, E grubu meslek hastalıkları grubu olan fiziksel etkenlerle olan meslek hastalıkları içinde yer almaktadır. SGK'ya bildirilen gürültüye bağlı işitme kaybı yaşayan sigortalı sayıları Şekil 2'de verilmiştir. 


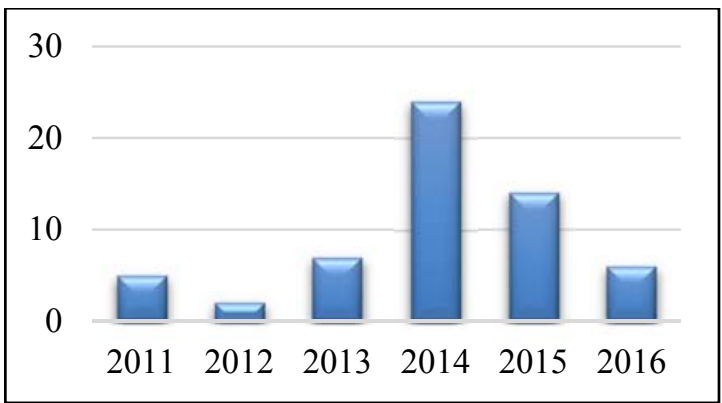

Şekil 2. Gürültüye bağl1 işitme kayb1 yaşayan sigortalı sayıları [9]

Şekil 2 incelendiğinde en fazla işitme kaybı yaşanan y1l 2014 yılı ve 24 kişi olarak gerçekleştiği görülmektedir. 2012 yılında ise sadece 2 kişi bildirilmiştir. Bu kadar az sayıda işitme kaybı bildiriminin yapılmış olması ișletmelerde tam olarak tespit edilerek kayıt altına alınmadığını düşündürmektedir.

SGK'ya bildirilen gürültüye bağlı ișitme kaybının meslek hastalıkları içindeki yüzdesi ise Şekil 3'de verilmiştir.

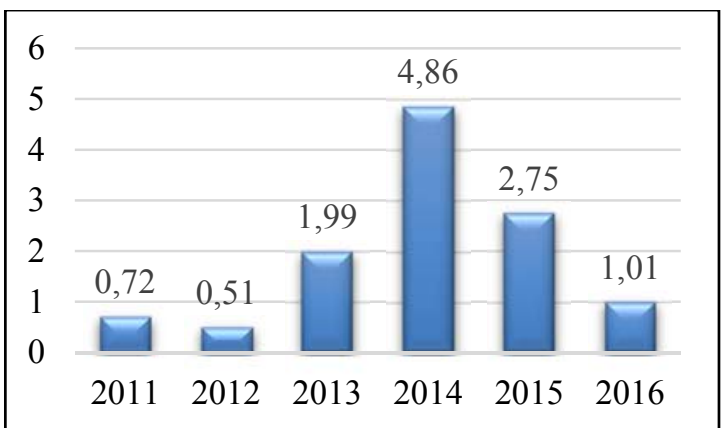

Sekil 3. İșitme kaybının meslek hastalıkları içindeki yüzdesi

Şekil 3 incelendiğinde 24 kişinin işitme kaybına yakalandığ bildirilen yıl olan 2014 yılında bu oran $\% 4,86$ olarak 2015 yılinda $\% 2,75$ olarak belirlenmiş̧tir. Diğer ylllarda ortama \%1 kişinin işitme kaybına yakalandığı belirlenmiştir.

\section{LOJISTIKK REGRESYON ANALIZİ}

Lojistik regresyon analizi verilerin kategorik analizinde de kullanılmakta olup, kategorik veri analizleri son y1llarda ölümlü kazalar üzerinde etkili parametrelerin etkileşimlerinin belirlenmesinde [10] ve ayrıca yaralanmalı kazalar üzerinde etkili parametrelerin etkileşimlerinin belirlenmesinde [11] kullanılmıştır. Ayrıca, meydana gelen iş kazalarında işgünü kayıplarının tahmin edilmesi için model oluşturmada $[12,13]$ ve toza bağlı meslek hastalıklarının oluşumunda etkili olan parametrelerin etkileşimlerinin belirlenmesinde $[14,15]$ kullanılmaktadır. Bunların dışında, oda topuk yöntemi ile çalışılan bir kömür madeninde tavan taşı düşme riski [16] ve yine bir kömür madenindeki baca içindeki ani metan püskürmesi gerçekleşme olasıllığı [17] lojistik regresyon ile değerlendirilmiştir. Ayrıca bir başka çalışmada, heyelan duyarlılığını belirlemek amacıyla lojistik regresyon analizini de içeren bir çalışma yapılmış ve lojistik regresyonun iyi bir modelleme yaptığ 1 bulunmuştur [18].

Lojit regresyon özellikle ikili bağımlı değişken için tasarlanmış doğrusal olmayan bir regresyon modelidir. Lojit regresyon modeli uygun dönüşümler ile doğrusallaştırılabilen bir doğrusal olmayan modeldir. Literatürde, lojit regresyon aynı zamanda "Lojistik Regresyon" olarak da adlandırılmaktadır [19].

Lojistik regresyon, bağımlı değişkenin tahmini değerlerini olasılık hesaplayarak, olasilık kurallarına uygun sınıflama yapma imkânı veren istatistiksel yöntemdir. Lojistik regresyon tablolaştırılmış ya da ham veri setlerini analiz eden bir yöntemdir [20].

Lojistik regresyon analizi, bağımlı değişkenin kategorik bir yapıya sahip olduğu, bağımsız değişkenlerin ise sürekli veya kategorik bir yapıda olabildiği durumlarda kullanılan bir tekniktir. Bağımlı değişken iki mümkün değer aldığında yani bu değişken iki şıklı (binary veya dichotomous) değişken olarak adlandırıldığı durumda modeldeki bağımlı değişken mümkün iki sonuçtan hangisinin gerçekleştiğine bağlı olarak 1 veya 0 değerini alır [21]. Bu çalışmada da ikili lojistik regresyon analizi kullanılarak model oluş̧urulmuştur.

Regresyon yöntemleri, bir yanıt değişkeni ile bir veya daha fazla açıklayıcı değişken arasındaki 
ilişkiyi açıklayan veri analizinin ayrılmaz bir bileşeni haline gelmiştir. Çoğunlukla, sonuç değişkeni ayrıktır ve iki veya daha fazla olası değer içerir [22]. Lojistik regresyon, bir olayın olasılığını tahmin etmek için kullanılan ve kategorik yanıt verileri için en önemli model olan istatistiksel bir yöntemdir [23]. Doğrusal regresyon, beklenen Y değerinin ve belirli bir $\mathrm{x}$ değerinin, $\mathrm{x}$ için lineer bir denklem olarak ifade edilebileceğini varsayar, örneğin, $\mathrm{E}(\mathrm{Y} \mid \mathrm{x})=\beta_{0}+\beta_{1} \mathrm{x}$. Bu ifade, $\mathrm{x}$ 'in $\mathrm{E}(\mathrm{Y} \mid \mathrm{x})$ için $-\infty$ ve $+\infty$ arasında değişebileceği anlamına gelir. Lojistik regresyon modeli genel olarak Eşitlik 1'deki gibi ifade edilir.

$\pi(x)=e^{\beta_{0}+\beta_{1} x} /\left(1+e^{\beta_{0}+\beta_{1} x}\right)$

Çoklu lojistik regresyon modelinin lojiti Eşitlik 2 kullanılarak belirlenir:

$\mathrm{g}(\mathrm{x})=\beta_{0}+\beta_{1} \mathrm{x}_{1}+\beta_{2} \mathrm{x}_{2}+\ldots+\beta_{\mathrm{p}} \mathrm{x}_{\mathrm{p}}$

Lojistik regresyon modeli Eşitlik 3'de verildiği şekildedir [22]:

$\pi(\mathrm{x})=\mathrm{e}^{\mathrm{g}(\mathrm{x})} /\left(1+\mathrm{e}^{\mathrm{g}(\mathrm{x})}\right)$

Lojistik regresyon analizi işitme kaybı yaşama ya da yaşamama olasılıklarını tahmin etmek için kullanılabilmektedir. İşitme kaybını etkileyen değişkenler Eşitlik 4'de yaş $\left(x_{1}\right)$, deneyim $\left(x_{2}\right)$, Laeq $\left(x_{3}\right)$, Ppeak $\left(x_{4}\right)$, Lex $\left(x_{5}\right)$ ve meslek grupları $\left(x_{6}\right)$ olarak verilmiştir. İşitme kaybı ikili (var-yok) bağımlı değişken, diğer değişkenler bağımsız değişken olarak alınmıştır.

$\pi(x)=\frac{e^{\beta_{0}+\beta_{1} x_{1}+\beta_{2} x_{2}+\beta_{3} x_{3}+\beta_{4} x_{4}+\beta_{5} x_{5}+\beta_{6} x_{6}}}{\left(1+e^{\beta_{0}+\beta_{1} x_{1}+\beta_{2} x_{2}+\beta_{3} x_{3}+\beta_{4} x_{4}+\beta_{5} x_{5}+\beta_{6} x_{6}}\right)}$

$\pi(x)$ : İncelenen olayın gözlenme olasılığg

$\beta_{0}, \beta_{1}, \beta_{2}, \beta_{3}, \beta_{4}, \beta_{5}, \beta_{6}:$ Katsayılar

$\mathrm{x}_{1}, \mathrm{x}_{2}, \mathrm{x}_{3}, \mathrm{x}_{4}, \mathrm{x}_{5}, \mathrm{x}_{6}$ : Bağımsız değişkenler

Lojistik regresyon analizinin önemli kavramlarından biri de Odds (olasılık) oranıdır. Çeşitli kaynaklarda bahis oranı, üstünlük oranı, olasılık oranı veya teklik oranı olarak da adlandırılan Odds oranı, bir olayın meydana gelme olasılığının meydana gelmeme olasılığına oranı olarak tanımlanabilir. Lojistik regresyon modelinin lojiti olarak atıfta bulunulan $\mathrm{g}(\mathrm{X})$ ifadesinin anti logaritması alındığında Odds oranına ulaşıldığı görülür [24]. Odds oranı (Eşitlik 5) olasılık kavramı ile yakından ilişkilidir.

$\mathrm{OR}=\exp [\mathrm{g}(\mathrm{X})]=\mathrm{e}^{\beta_{0}}\left(\mathrm{e}^{\beta_{1}}\right)^{\mathrm{X}}=\left[\frac{\pi(\mathrm{X})}{1-\pi(\mathrm{X})}\right]$

Modelde bulunan her bir parametrenin $\operatorname{Exp}(\beta)$ değerleri olasılık oranları olarak ele alınır. Böylece $\operatorname{Exp}\left(\beta_{\mathrm{k}}\right), \mathrm{Y}$ değişkeninin $\mathrm{X}_{\mathrm{k}}$ değiş̧keninin etkisi ile kaç kat daha fazla ya da \% kaç oranda fazla gözlenme olasılığına sahip olduğunu belirtir. $\beta_{\mathrm{k}}$ katsayısının istatistiksel anlamlılığı aynı zamanda $\mathrm{OR}=\operatorname{Exp}\left(\beta_{\mathrm{k}}\right)$ 'nın da istatistiksel anlamlılığ 1 olarak değerlendirilir [20].

Odds oranının yorumu kısaca özetlenecek olunursa; 1'den büyük bir Odds oranı olayın gerçekleşmesinin olabilirliğinin arttığını, 1'den küçük bir Odds oranı ise olayın gerçekleşmesinin olabilirliğinin azaldığını göstermektedir [25]. Eğer modeldeki " $\beta$ " regresyon katsayıları negatif değerli ise, bu katsayıların Odds oranı $(\operatorname{Exp}(\beta))$ değerlerinin (Odds oranı $=1 / \operatorname{Exp}(\beta))$ biçiminde düzeltilmesi ve yorumların bu değerlere göre yapılması gerekir [20].

Bağımlı değişkenin bağımsız değişkenler tarafından ne derece tanımlanabildiğinin tespit edilebilmesi için katsayıların istatistiksel anlamlılığı, yani kurulan modelin uyum iyiliği test edilmelidir. Katsayıların bireysel anlamlılıklarının değerlendirilmesinde kullanılan bir diğer ölçüt ise, Wald testidir. Çoklu doğrusal regresyon analizinde, modeldeki bağımsız değişkenlerin bağımlı değişken üzerinde istatistiksel olarak anlamlı bir katkısının olup olmadığını belirlemede, diğer bir deyişle parametrelerin anlamlılığını test etmede $\mathrm{t}$ testinden yararlanılır [26]. Ancak Wald testi, $\mathrm{t}$ istatistiği ile aynı formda olmasına rağmen $\mathrm{t}$ dağılımına uymamakta ve $\mathrm{z}$ dağılımı göstermektedir [27]. Bu nedenle lojistik regresyon analizinde aynı amaçla Wald istatistiği kullanılır. Çoklu regresyon katsayılarının anlamlılığının testinde kullanılan standart hata yaklaşımı ile aynı 
mantığa sahip olan Wald test istatistiği değeri $\left(\mathrm{W}_{\mathrm{k}}\right)$, bağımsız değişkenlere ait eğim katsayısının $(\beta)$, kendi standart hatasına (SE) oranlanmasi sonucu,

$\mathrm{W}_{\mathrm{k}}=\left[\frac{\beta-0}{\operatorname{SE}(\beta)}\right]^{2}$

Eşitlik 6'da verildiği şekilde elde edilir [23].

$\mathrm{Bu}$ istatistik;

$\mathrm{H}_{0}: \beta_{\mathrm{i}}=0$

$\mathrm{H}_{1}: \beta_{\mathrm{i}} \neq 0$ (en az bir $\beta_{\mathrm{i}}$ sıfırdan farklıdır $(\mathrm{i}=1,2, \ldots, \mathrm{k}$ olmak üzere) hipotezleri için belirlenen bir güvenilirlik seviyesinde $(\mathrm{k})$ serbestlik derecesinde $\chi^{2}$ dağılımına ait tablo değeri ile karşılaştırılarak test edilir. Eğer hesaplanan Wald test istatistiği değeri Wald test istatistiğinin tablo değerinden büyük veya eşit ise $\mathrm{H}_{1}$ hipotezi kabul edilir. $\mathrm{Bu}$ varsayımdan hareketle testi yapılan değişkenlerin istatistiksel olarak anlamlı olduğu söylenebilir.

Lojistik regresyon modelinin uyum iyiliği testi için kullanılan bir başka yöntem de sınıflandırma tablolarıdır. Sınıflandırma tablosunda bağımlı değişkeninin gözlenen ve kestirilen lojistik olasılıklarından türetilen " 0 " veya "1" değerleri yer almaktadır [28]. Bu tablolar bağımlı değişkenin gözlenen gerçek değerleri ile tahmin edilen değerlerinin çaprazlanması sonucu meydana gelir. Sinıflandırma tablosunu oluşturmak için öncelikle bir kesim değeri (c) belirlenir ve tahmin edilen değerler, bu sınır değer ile karşılaştırılarak uygun gruba ataması yapılır. Tahmin edilen değer, c değerini aşar ise 1 grubuna, aşmaz ise 0 grubuna atanır. Burada sözü edilen sınır değeri c için genellikle 0,5 değeri kullanılır [29]. Tablodaki sinıflandırma yüzdelerinin yüksek olması sınıflandırmanın doğru yapıldığını ve uyumun iyi olduğunu gösterecektir [28].

\section{UYGULAMA ÇALIŞMASI}

Uygulama çalışması yeraltı işletme yöntemi ile üretim yapan bir metal madeni işletmesinde gerçekleştirilmiştir. İşletmede çeşitli görevleri yürüten 109 çalışan bulunmaktadır. Cevher üretimi kes-doldur yöntemi ile yapılmakta olup, mekanize ekipmanlarla gerçekleştirilmektedir. Çalışanlar çoğunlukla farklı iş makinalarını kullanan operatörlerden oluşmaktadır. Tahkimat, püskürtme beton ve kaya saplaması ile sağlanmaktadır. Yeraltı ocak girişi ve havalandırma sistemi Şekil 4'de görülmektedir.

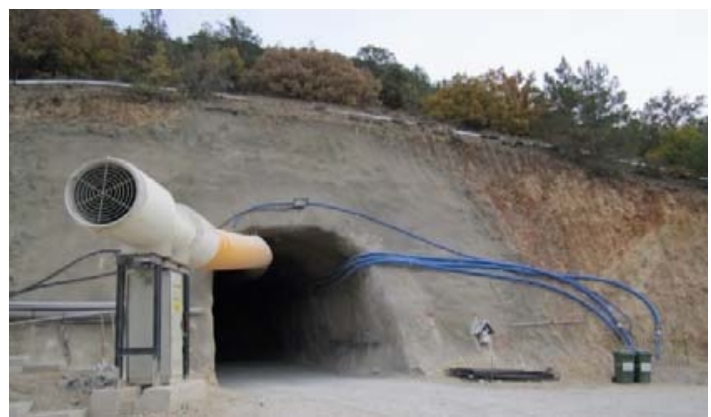

Şekil 4. Ocak hava girişi

Yeraltından pasa ve cevher çıkarmada, küçük ve orta ölçekli yeraltı çalışmaları için geliştirilmiş olan eğimli bölgelerde rahatlıkla kullanılabilen 20 metrik ton kapasiteli Minetruck MT2010 yeraltı kamyonu kullanılmaktadır. İşletmede kullanılan yeraltı kamyonu Şekil 5'de verilmiştir.

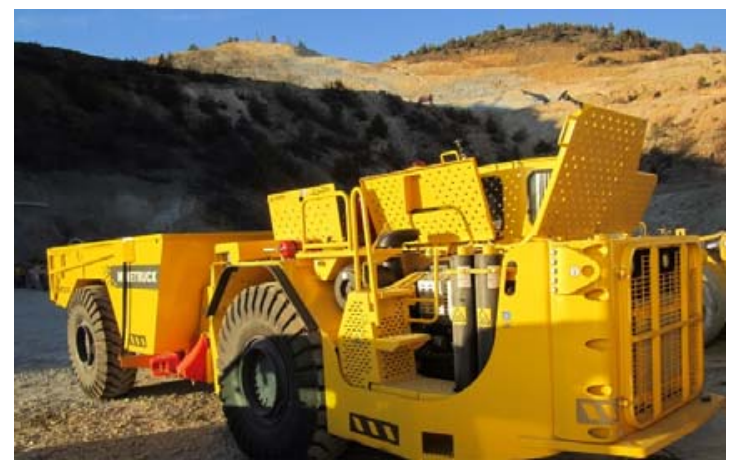

Şekil 5. Minetruck yeraltı kamyonu

Hidrolik delici makine (Jumbo) olarak, kesiti $45 \mathrm{~m}^{2}$ ye kadar olan küçük ve orta ölçekli tüneller ve maden üretim uygulamalarında kullanılmaya uygun, Boomer 282 iki kollu delici kullanılmaktadır. Daha büyük delik ve daha zorlu koşullarda delme işlemlerinde, 51 - 89 mm delik aralığında küçük ve orta boy galerilerde uzun delik açma işlemlerinde, yukarıya ve aşağıya doğru ve yan duvarlarda paralel delikler açabilen Simba 1354 
kaya delici kullanılmaktadır. İşletmede Jumbo çalışırken görünümü Şekil 6'da ve Simba delicisinin görünümü Şekil 7'de verilmiştir.

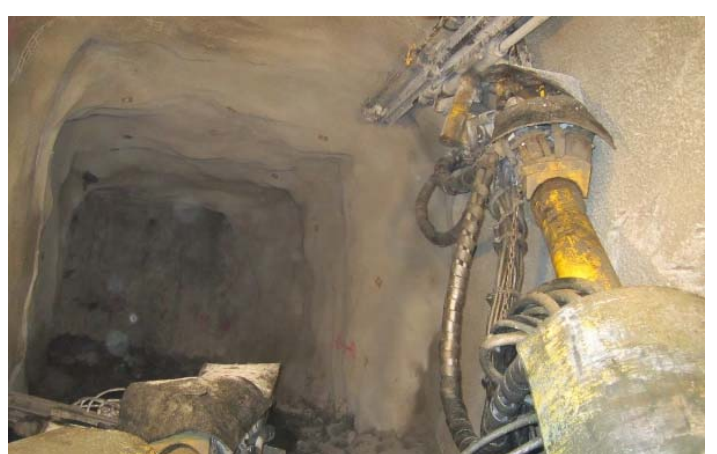

Şekil 6. İşletmede Jumbo çalışırken görünümü

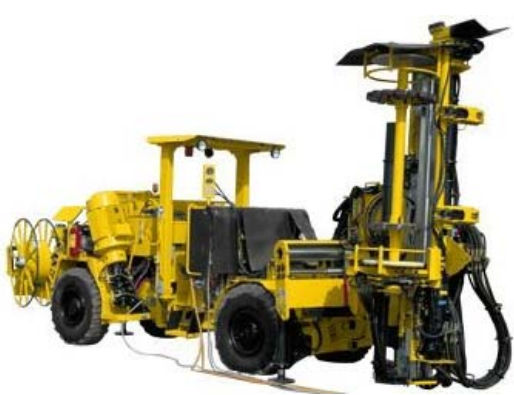

Şekil 7. Simba delicisi

Yükleyici (loader) olarak, 6.8 metrik ton kapasiteli LHD Scooptram ST7 yeraltı yükleyicisi kullanılmaktadır. İşletmede loader çalışırken görünümü Şekil 8'de verilmiştir.

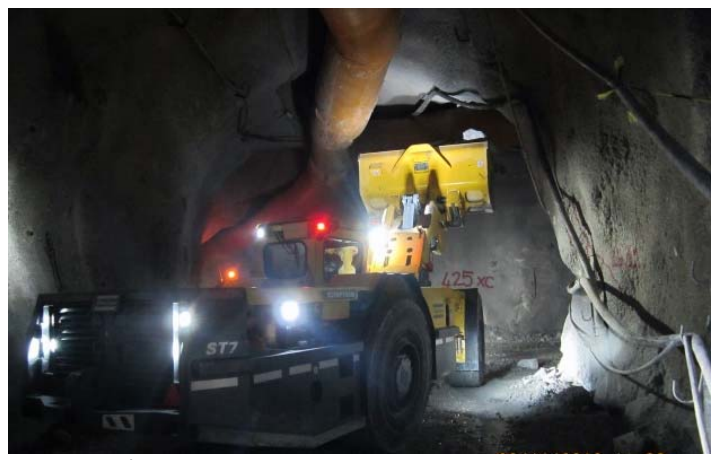

Şekil 8. İşletmede loader çalışırken görünümü

Tahkimat işlemlerinde, 1,5 ile 2,4 m uzunluğundaki c1vatalar (bulonlar) ve 8,5 m yüksekliğe kadar olan tavanlarda kullanılan tamamen mekanik kaya civatalama (bulonlama) makinesi olan Boltec 235 kullanılmaktadır. Konumlama, delme ve cıvatalamanın kontrolü için Doğrudan Kontrol Sistemi (DCS) ve özellikle bulon deliği delmek için tasarlanan COP 1132 hidrolik kaya delicisi ile donatılmıştır. İşletmede cıvatalama makinesi çalışırken görünümü Şekil 9'da verilmiştir.

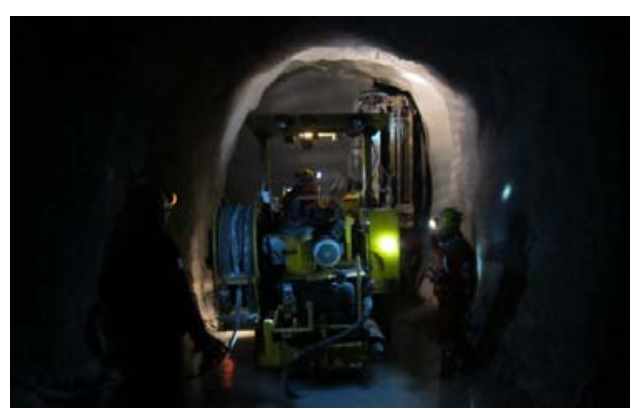

Şekil 9. İşletmede cıvatalama makinesi çalışırken görünümü

Beton püskürtme işlemlerinde, $34 \mathrm{~m}^{3} /$ saat teorik beton püskürtme kapasitesine sahip Titan marka makine kullanılmaktadır. İşletmede beton püskürtme makinesi çalışırken görünümü Şekil 10'da verilmiştir.

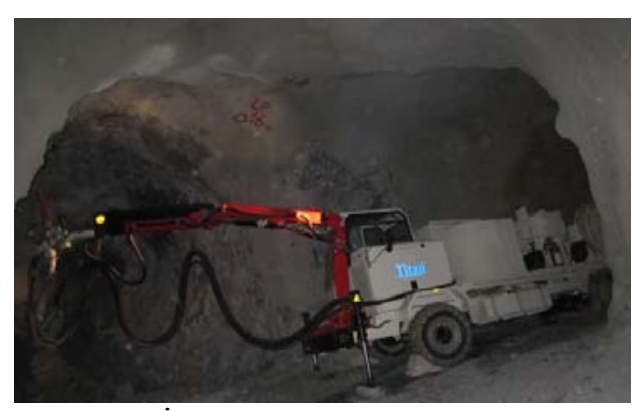

Şekil 10. İşletmede beton püskürtme makinesi çalışırken görünümü

Ortam gürültü ölçümleri SVAN 958 marka portatif gürültü ve titreşim ölçüm cihazı ile yapılmıştır. Cihaz, değişik ölçüm noktalarında ortam seviyesine göre değişik ölçüm aralıklarını otomatik olarak belirlemekte ve ölçümleri hafızasına otomatik olarak kaydetmektedir. Cihazın dinamik ölçüm aralığı 0-140 dB'dir. Cihaz ile eşdeğer gürültü seviyesi (Leq), LEX, ortalama, minimum ve maksimum gürültü seviyeleri ölçülebilmektedir. 
Kişisel gürültü maruziyet ölçümleri CASELLA marka CEL-350 cihazı ile 8 saatlik çalışma süresi boyunca yapılmıştır. Cihaz ölçüm süresince topladığı tüm veriyi bilgisayara aktarılıncaya kadar hafizasında saklı tutmaktadır. Aynı anda ISO ve OSHA standartlarına uygun ölçüm alarak ilgili tüm parametreleri ayrı ayrı sağlamaktadır. Lineer çalışma aralığı 65,0-140,3 dB(A), peak ölçüm aralığı ise 95,0-143,3 dB(C)'dir [30].

Yeraltı metal madeni işletmesinde çalışanlar 22-53 yaş aralığında olup, yaş gruplarına göre dağılımı Şekil 11'de verilmiştir.

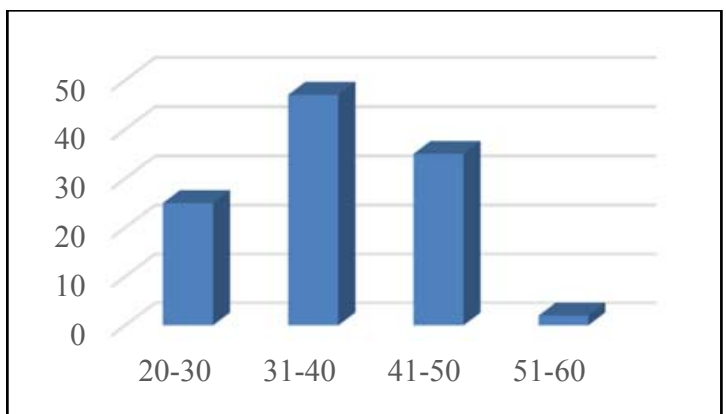

Şekil 11. Çalışanların yaş aralıklarına göre dağılımı

Şekil 11'den de görüldüğü gibi çalışanların $\% 43$ 'ünü 31-40 yaş arası çalışanlar ve \%32'sini 41-50 yaş arası çalışanlar oluşturmaktadır. Çalışanların işletmedeki deneyim süreleri 1-7 yıl arasında değişmektedir. Şekil 12'de çalışanların deneyim süreleri yüzde dağılımları verilmiştir.

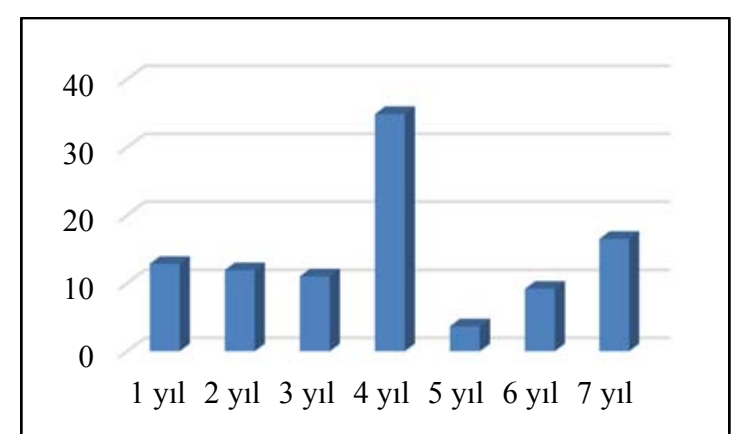

Şekil 12. Çalışanların deneyim süreleri dağı̆lımları

Şekil 12 incelendiğinde, çalışanların \%34,86's1 4 yıllık, \%16,5'i 7 yıllık deneyime sahip olduğu görülmektedir.
İşletmede meslekler 6 grupta toplanmış olup bunlar; beton pompası operatörü, jumbo operatörü, loader operatörü, simba operatörü, yeraltı kamyonu operatörü ve tahkimatçıdır. Şekil 13'de mesleklerine göre çalışan dağılımları verilmiştir.

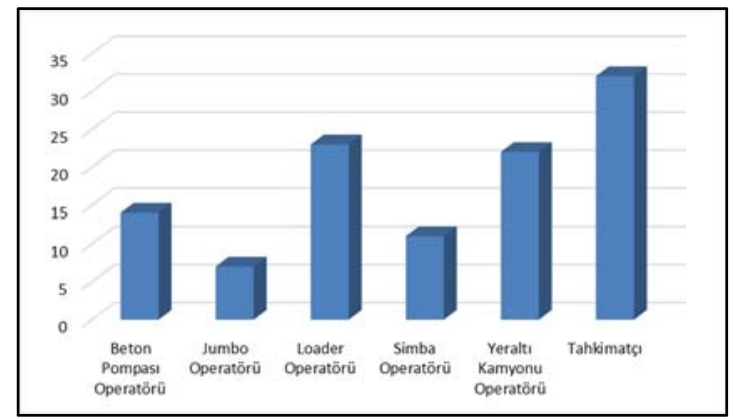

Şekil 13. Mesleklerine göre çalışan dağılımları

Şekil 13 incelendiğinde, 32 çalışanın tahkimatçı, 23 çalışanın loader operatörü, 22 çalışanın yeraltı kamyon operatörü, 14 çalışanın beton pompası operatörü, 11 çalışanın simba operatörü ve 7 çalışanın da jumbo operatörü olarak çalıştığı görülmektedir. Jumbo operatörünün sorumluluğu aynada delik delme işlemini gerçekleştirmek, loader operatörünün sorumluluğu yeraltındaki pasa ve patlatma işlemi sonrasında gevşetilmiş cevherin yükleme işini yapmak, yeraltı kamyonu operatörünün sorumluluğu yeraltından pasa ve cevher çıkarmaktır. Tahkimatçının (Boltec operatörü) sorumluluğu, kaya civatalama işini yapmak, beton pompası operatörünün sorumluluğu tahkimat için beton püskürtme işlemini yapmak ve simba operatörünün sorumluluğu ise, daha büyük delik ve daha zorlu koşullarda delme işlemini yapmaktır. İşletmede ortamın eşdeğer gürültü seviye (Laeq) değerleri 79,5-99,6 dB(A) aralı̆̆ında, darbe gürültü düzeylerinin (Ppeak) $125-140,9 \mathrm{~dB}(\mathrm{C})$ aralığında ve çalışanların maruz kaldıkları gürültü düzeylerinin (Lex) 79-99,6 dB(A) aralığında değiştiği belirlenmiştir. Lojistik regresyon analizinde, yaş, deneyim, Laeq, Ppeak, Lex değişkenleri sürekli, meslek ise kategorik olarak alınmıştır. Çalışmada, bağımlı değişken olan gürültüye bağlı işitme kayıpları üzerine, bağımsız değişkenler olan yaş, deneyim, Laeq, Ppeak, Lex ve meslek gruplarının etkisinin araştırılması amaçlanmıştır. Değerlendirmeye alınan 
parametrelerin her biri ile gürültüye bağlı işitme kayıpları arasında ikili lojistik regresyon analizi yapılmış ve elde edilen sonuçlar Çizelge 2'de verilmiştir.

Çizelge 2. İkili lojistik regresyon sonuçları

\begin{tabular}{|l|l|l|l|l|l|l|}
\hline & $\beta$ & S.E. & Wald & Sig. & $\operatorname{Exp}(\beta)$ & $1 / \operatorname{Exp}(\beta)$ \\
\hline Yaş & -.011 & .005 & 4,022 & $.045^{*}$ & .990 & 1,010 \\
Deneyim & -.117 & .046 & 6,538 & $.011^{*}$ & .889 & 1,125 \\
Laeq & -.006 & .002 & 7,198 & $.007^{* *}$ & .994 & 1,006 \\
Ppeak & -.004 & .001 & 7,276 & $.007^{* *}$ & .996 & 1,004 \\
Lex & -.006 & .002 & 7,273 & $.007 * *$ & .994 & 1,006 \\
Yeraltı Kamyonu Operatörü & & & 11,155 & $.048^{*}$ & & \\
Beton Pompası Operatörü & $-1,299$ & .651 & 3,979 & $.046^{*}$ & .273 & 3,663 \\
Jumbo Operatörü & -.288 & .764 & .142 & .706 & .750 & 1,333 \\
Loader Operatörü & $-1,041$ & .475 & 4,810 & $.028^{*}$ & .353 & 2,833 \\
Simba Operatörü & -.981 & .677 & 2,099 & .147 & .375 & 2,667 \\
Tahkimatç1 & -.125 & .354 & .125 & .724 & .882 & 1,134 \\
\hline
\end{tabular}

* \%95 güvenilirlik seviyesinde anlamlı

** \%99 güvenilirlik seviyesinde anlamlı

ßo ortamda gürültü ve insan olmaması durumunda anlamlı bir parametre olduğundan modele dahil edilmemiştir. Çizelge 2'den tüm değişkenlerle işitme kayıpları arasında anlamlı bir ilişki olduğu ve model oluşturmada kullanılabileceği yorumu yapılabilir. $\% 95$ güvenilirlik seviyesinde $\chi^{2}$ değeri 3,84 'tür ve istatistiksel olarak anlamlı bulunan tüm değişkenlerin katsayılarının Wald test istatistiğine göre de anlamlı olduğu bulunmuştur. Ayrıca deneyimin 1 yıl artması ile işitme kaybı yaşamama olasılığının 1.125 kat arttığı belirlenmiştir. Yeraltı kamyonu operatörüne göre, beton pompası operatörünün işitme kaybı yaşamama olasılığının 3.663 kat, loader operatörünün ise 2.833 kat daha

Çizelge 3. Eşitlikteki değişkenler

\begin{tabular}{|c|c|c|c|c|c|c|c|}
\hline & & $\beta$ & S.E. & Wald & $\mathrm{df}$ & Sig. & $\operatorname{Exp}(\beta)$ \\
\hline \multirow[t]{10}{*}{ Step 1} & Yaş & .121 & .038 & 10.305 & 1 & $.001 * * *$ & 1.129 \\
\hline & Deneyim & -.183 & .180 & 1.030 & 1 & .310 & .833 \\
\hline & Laeq & -.410 & .813 & .254 & 1 & .614 & .664 \\
\hline & Ppeak & -.034 & .066 & .265 & 1 & .607 & .967 \\
\hline & Lex & .423 & .812 & .272 & 1 & .602 & 1.527 \\
\hline & Meslek & & & 1.553 & 4 & .817 & \\
\hline & Meslek(1) & -1.327 & 1.463 & .823 & 1 & .364 & .265 \\
\hline & $\operatorname{Meslek}(2)$ & .396 & 1.004 & .156 & 1 & .693 & 1.486 \\
\hline & Meslek(3) & -.734 & .942 & .607 & 1 & .436 & .480 \\
\hline & Meslek(4) & -1.456 & 1.442 & 1.019 & 1 & .313 & .233 \\
\hline \multirow[t]{5}{*}{ Step 2} & Yaş & .117 & .035 & 11.126 & 1 & $.001 * * *$ & 1.124 \\
\hline & Deneyim & -.117 & .148 & .628 & 1 & .428 & .890 \\
\hline & Laeq & .392 & .344 & 1.298 & 1 & .255 & 1.480 \\
\hline & Ppeak & -.069 & .042 & 2.719 & 1 & .099 & .933 \\
\hline & Lex & -.345 & .325 & 1.129 & 1 & .288 & .708 \\
\hline \multirow[t]{4}{*}{ Step 3} & Yaş & .106 & .032 & 11.062 & 1 & $.001 * * *$ & 1.112 \\
\hline & Laeq & .542 & .290 & 3.489 & 1 & $.062 *$ & 1.719 \\
\hline & Ppeak & -.083 & .039 & 4.443 & 1 & $.035 * *$ & .921 \\
\hline & Lex & -.479 & .279 & 2.940 & 1 & $.086^{*}$ & .620 \\
\hline
\end{tabular}

* \%90 güvenilirlik seviyesinde anlamlı, ** \%95 güvenilirlik seviyesinde anlamlı, *** \%99 güvenilirlik seviyesinde anlamlı

fazla olduğu belirlenmiştir. İşitme kayıları üzerinde sadece yaş veya gürültü düzeylerinin işitme kaybı yaşama olasılığını artırmadı̆̆ı görülmüştür. Tüm değişkenlerle işitme kaybı yaşama olasılığını tahmin etmede kullanılabilecek bir model oluşturmak için lojistik regresyon analizi uygulanmıştır. İlk modelde tüm değişkenler modele katılmış ancak yaş hariç diğer değişkenlerin anlamlı olmadığı belirlenmiştir. İkinci modelde meslek kategorisi modelden çıkartılmış ancak yine yaş değişkeni hariç diğer değişkenlerin anlamlı olmadığı belirlenmiştir. Üçüncü ve son oluşturulan modele dâhil olan tüm değişkenler anlamlı bulunmuştur ve elde edilen sonuçlar Çizelge 3'de verilmiştir. 
Çizelge 3'de oluşturulan lojistik regresyon modeli katsayıları $(\beta)$ kullanılarak işletmede işitme kayıpları yaşama olasılıklarını tahmin etmek mümkündür. \%99 güvenilirlik seviyesinde yaşın işitme kayıplarında etkili olduğu söylenebilir. Modelin anlamlılı̆̆ını test etmek için Hosmer-Lemeshow testi yapılmış test değeri 4,841 ve $p$ değeri 0,774 olarak bulunmuştur $(p>0,005$ olduğundan model anlamlıdır). Kurulan model Eşitlik 7'de verilmiştir.

$$
\widehat{Y}=0,106 X_{(\text {Yaş) }}+0,542 X_{(\text {Leq) }}-0,083 X_{(\text {Ppeak })}-0,479 X_{(\text {Lex })}
$$

Burada kurulan model gürültüye bağlı işitme kaybını tahmin etmede kullanılabilecek bir eşitlik olup, işletmeye özeldir. Bu modeldeki değişkenler kullanılarak hesaplama yapıldığında, bulunan değer 0,5 'in altında ise işitme kaybı yaşama olasılığının azaldığ 1 , üzerinde ise arttığ 1 yorumu yapılabilir [20]. Kurulan model ile yaş değişkenindeki 1 birimlik artışın işitme kaybı olasılığını 1,112 kat artırdığı; ortamın eşdeğer gürültü seviyesindeki (Laeq) $1 \mathrm{~dB}(\mathrm{~A})^{\prime} l \mathrm{l} \mathrm{k}$ artışın işitme kaybı olasılığını 1,719 kat artırdığ1; negatif katsayılı değişkenlerden darbe gürültü düzeyindeki (Ppeak) $1 \mathrm{~dB}(\mathrm{~A})$ 'llk artışın işitme kaybı yaşamama olasılığını 1,086 kat artırdığı; çalışanların maruz kaldıkları gürültü düzeyindeki (Lex) 1 dB(A)’lık artışın işitme kaybı yaşamama olasılığını 1,612 kat artırdığ 1 yorumu yapılabilir. Elde edilen eşitliğin doğru tahmin sınıflandırma tablosu ise Çizelge 4'de verilmiştir.

Çizelge 4. Modelin sınıflandırma tablosu

\begin{tabular}{|c|c|c|c|}
\hline \multirow{2}{*}{ Gözlenen } & \multicolumn{3}{|c|}{ Tahmin } \\
\cline { 2 - 3 } & \multicolumn{2}{|c|}{ İitme kayb1 } & Doğrulama \\
\cline { 2 - 3 } & 0 & 1 & yüzdesi \\
\hline 0 & 57 & 12 & 82,6 \\
\hline 1 & 24 & 16 & 40,0 \\
\hline Tüm Oranlar & & & 67,0 \\
\hline
\end{tabular}

Modelde kullanılan 109 çalışana ait işitme kaybı test sonuçlarına göre, 69 çalışanda işitme kaybı yokken, 40 çalışanda işitme kaybı mevcuttur. Çizelge 3'e göre kurulan modelin sınıflandırması, işitme kaybı olmayan 69 çalışanın 57 adedinde kayıp olmadığı 12 adedinde işitme kaybı olduğu, işitme kaybı olan 40 çalışanın 24 adedinde kayıp olmadığ 16 adedinde işitme kaybı olduğu şeklinde gerçekleşmiştir. Böylece elde edilen denklemin işitme kaybı bulunmamasını doğru tahmin etme oranı \%82,6, işitme kaybı olmasını doğru tahmin etme oranı $\% 40$, modelin genel olarak doğru siniflandırma oranının ise, $\% 67$ olduğu belirlenmiştir.

\section{SONUÇ VE ÖNERÍLER}

$\mathrm{Bu}$ çalışmada, bir yeraltı metal madeninde çalışanların gürültüye bağlı işitme kayıplarını incelemek amacıyla, çalışanların maruz kaldıkları ortalama gürültü düzeyleri, ortamın ortalama gürültü düzeyleri ve darbe gürültü düzeyleri, meslek grupları, yaş ve deneyim süreleri göz önüne alınarak lojistik regresyon analizi kullanılmış ve işitme kayıplarının tahmini için bir model oluşturulmuştur.

Tüm değişkenler birlikte değerlendirildiğinde, gürültüye bağlı işitme kaybındaki en önemli etkenlerin, çalışanların yaşları ve ortamın gürültü düzeyi olduğu bulunmuştur. Çalışanların maruz kaldıkları gürültü düzeyi ve ortamdaki darbe gürültü düzeylerinin işitme kaybı yaşamama olasılıklarını artırdığı yönde etkisinin olduğu bulunmuştur. $\mathrm{Bu}$ durum çalışanların ortamdaki yüksek düzeydeki gürültüyü algıladıklarında kişisel koruyucularını kullandıklarını düşündürmektedir. İşitme kaybı yaşama olasılıklarının, yeraltı kamyon operatörüne göre, sirasiyla beton pompası operatörü, loader operatörü ve simba operatörünün daha yüksek olduğu tespit edilmiştir.

Kurulan modelle herhangi bir çalışan için gürültüye bağlı işitme kaybı yaşama ya da yaşamama olasılığ yüksek bir güvenilirlikle tespit edilebilir. Elde edilen bu sonuçlar doğrultusunda, ortamdaki gürültü düzeyini artıran en önemli kaynakların iş makinaları olduğu ve dolayısıyla öncelikli kontrolün bu makinalarda yapılması gerektiği açığa çıkmaktadır. Çalışan yaşının önemli olarak ön plana çıkması da, ileri yaştaki çalışanların daha sık sağlık kontrolünden geçmelerini zorunlu hale getirmiştir.

Meslek hastalıkları konusunda işveren ve çalışanların bilgilendirilmesi ve duyarlıklarının 
sağlanması önemlidir. Bu çalışma, gürültüye bağlı işitme kayıplarının incelenmesi amacıyla yapılmış olup, farklı meslek hastalıkları için de gerçekleştirilebilir. Böylece elde edilecek sonuçlar doğrultusunda işletmeler geleceğe yönelik daha duyarlı önlemleri hayata geçirebilirler.

\section{TEŞEKKÜR}

Çalışmaya olan katkılarından dolayı maden mühendisi Necip Orbay PEKİN'e teşekkür ederim.

\section{KAYNAKLAR}

1. Vipperman, J.S., Bauer, E.R., Babich, D.R. 2007. Survey of Noise in Coal Preparation Plants. Journal of the Acoustical Society of America, 121(1), 197-205.

2. Resmi Gazete., 1972. Sosyal Sigorta Sağlık İşlemleri Tüzüğü, 22.6.1972, Sayı No: 14223

3. Paunović, K., Jakovljević, B., Belojević, G., 2009. Predictors of Noise Annoyance in Noisy and Quiet Urban Streets. Science of the Total Environment, 407, 3707-3711.

4. Sharma, O., Mohanan, V., Singh, M., 1998. Noise Emission Levels in Coal Industry. Applied Acoustics, 54(1), 1-7.

5. Roy, S., Adhikari, G.R., 2007. Worker Noise Exposures From Diesel and Electric Surface Coal Mining Machinery. Noise Control Eng. J, 55, 434-437.

6. ÇŞB, 2018. T.C Çevre ve Şehircilik Bakanlığ (http://gurultu.cevreorman.gov.tr/gurultu/AnaS ayfa/gurultu.aspx?sflang=tr).

7. Resmi Gazete, 2013. Çalışanların Gürültü ile ilgili Risklerden Korunmalarına Dair Yönetmelik, 28.07.2013, Sayı: 28721.

8. Güven, R., 2011. Meslek Hastalıkları Rehberi. ÇSGB, İSGGM 2011, Ankara.

9. SGK, 2018. Sosyal Güvenlik Kurumu İstatistik Y1lları 2011-2016 Meslek Hastalıkları İstatistikleri. http://www.sgk.gov.tr

10. Önder, M., Adigüzel, E., 2010. Evaluation of Occupational Fatalities Among Uderground Coal Mine Workers Throught Hierarchical Loglinear Models, Industrial Health, 48(6), 872-878.
11. Onder, M., Onder, S., Adiguzel E., 2014. Applying Hierarchical Loglinear Models to Nonfatal Underground Coal Mine Accidents for Safety Management. International Journal of Occupational Safety and Ergonomics, 20(2), 239-248.

12. Onder, S., 2013. Evaluation of Occupational Injuries with Lost Days Among Opencast Coal Mine Workers Through Logistic Regression Models. Safety Science, 59, 86-92.

13. Onder, S., Mutlu, M., 2017. Analyses of Nonfatal Accidents in an Opencast Mine by Logistic Regression Model - a Case Study. International Journal of Injury Control and Safety Promotion, 24(3), 328-337.

14. Aydin, H., 2010. Evaluation of the Risk of Coal Workers Pneumoconiosis (CWP): A Case Study for the Turkish Hardcoal Mining. Scientific Research and Essays, 5(21), 3289-3297.

15. Önder, M., Önder, S., Demir İroz, B., Adıgüzel, E., 2017. Madencilikte Toza Bağlı Meslek Hastalıklarının Aşamalı Logaritmik Doğrusal Analiz ile İncelenmesi: TKİ Himmetoğlu Linyit Ocağı Örneği, Uluslararası Maden İşletmelerinde İşçi Sağlığı ve İş Güvenliği Sempozyumu 2017, 02-03 Kasım 2017, 583-596.

16. Palei, S.K., Das, S.K., 2009. Logistic Regression Model for Prediction of Roof Fall Risks in Bord and Pillar Workings in Coal Mines: An Approach, Safety Science, 47(1), 88-96.

17. Li, Z., Wang, E., Ou, J., Liu, Z., 2015. Hazard Evaluation of Coal and Gas Outbursts in a Coalmine Roadway Based on Logistic Regression Model, International Journal of Rock Mechanics and Mining Sciences, 80, 185-195.

18. Erener, A., Mutlu, A., Duzgun, H. S., 2016. A Comparative Study for Landslide Susceptibility Mapping Using GIS-based Multi-criteria Decision Analysis (MCDA), Logistic Regression (LR) and Association Rule Mining (ARM). Engineering Geology, 203, 45-55.

19. Stock, J.H., Watson, M.W., 2007. Introduction to Econometrics, Pearson Addison Wesley, Boston, 840 .

20. Özdamar, K., 2004. Paket Programlar ile İstatistiksel Veri Analizi 1, Kaan Kitabevi, Eskişehir, 649. 
21. Murat, D., 2006. Parasal Krizlerin İstatistiksel Analizi ve Türkiye Uygulaması, Uludağ Üniversitesi, Sosyal Bilimler Enstitüsü, Yüksek Lisans Tezi, s.129.

22. Hosmer, D.W., Lemeshow, S., 2000. Applied Logistic Regression, John Wiley and Sons, New York, 2, 373.

23. Agresti, A., 2002. Categorical data Analysis. New Jersey: John Wiley \& Sons, Inc.

24. Agresti, A., 1996. An Introduction to Categorical Data Analysis, John Wiley and Sons Inc., 372.

25. Tüzüntürk, S., 2007. Ekonometri Bölümü Mezunlarının Çalışma Hayatına Girişi: Deneysel Bir Alan Araştırması, 8. Türkiye Ekonometri ve İstatistik Kongresi, Malatya.

26. Tabachnick, B.G., Fidel, L.S., 1996. Using multivariate statistics, HarperCollins College Publishers, Third Edition, New York, p.581.

27. Gök, A.C., 2010. İletmelerin Tahminleme Sürecinde Bulanık Doğrusal Regresyon Analizi ve Lojistik Regresyon Analizinin Uygulanmas1, Yüksek Lisans Tezi, Dokuz Eylül Üniversitesi, Sosyal Bilimler Enstitüsü, İzmir

28. Aksaraylı, M., Saygın, Ö., 2011. Algılanan Hizmet Kalitesi ve Lojistik Regresyon Analizi ile Hizmet Tercihine Etkisinin Belirlenmesi, Dokuz Eylül Üniversitesi Sosyal Bilimler Enstitüsü Dergisi, 13(1), 21-37.

29. Murat, D., Işı̆̆ıçok, E., 2008. Expectations Regarding the Economic and Political Situation in the 2007 Election Period: the Case of Bursa, Uludağ Üniversitesi İktisadi ve İdari Bilimler Dergisi, 27(2), 1-24.

30. Başkent İSG, 2015. Başkent İş Sağlığı ve Güvenliği Çevre Ölçüm Merkezi, Ortam ve Kişisel Maruziyet Gürültü Ölçüm Raporu. 